\title{
Genetic Variation of Beta-carotene and Lutein Contents in Lettuce
}

\author{
Beiquan Mou ${ }^{1}$ \\ U.S. Department of Agriculture, Agricultural Research Service, 1636 East Alisal Street, Salinas, \\ CA 93905
}

AdDITIONAL INDEX WORDS. carotenoids, chlorophyll, provitamin A, nutrition, HPLC, breeding, germplasm, Lactuca sativa,
Lactuca serriola, Lactuca saligna, Lactuca virosa

ABstract. There is increasing medical evidence for the health benefits derived from dietary intake of carotenoid antioxidants, such as $\beta$-carotene and lutein. Enhancing the nutritional levels of vegetables would improve the nutrient intake without requiring an increase in consumption. A breeding program to improve the nutritional quality of lettuce (Lactuca sativa L.) must start with an assessment of the existing genetic variation. To assess the genetic variability in carotenoid contents, 52 genotypes including crisphead, leaf, romaine, butterhead, primitive, Latin, and stem lettuces, and wild species were planted in the field in Salinas, Calif., in the Summer and Fall of 2003 with four replications. Duplicate samples from each plot were analyzed for chlorophyll ( $a$ and $b$ ), $\beta$-carotene, and lutein concentrations by high-performance liquid chromatography (HPLC). Wild accessions (L. serriola L., L. saligna L., L. virosa L., and primitive form) had higher $\beta$-carotene and lutein concentrations than cultivated lettuces, mainly due to the lower moisture content of wild lettuces. Among major types of cultivated lettuce, carotenoid concentration followed the order of: green leaf or romaine $>$ red leaf $>$ butterhead $>$ crisphead. There was significant genetic variation in carotenoid concentration within each of these lettuce types. Crisphead lettuce accumulated more lutein than $\beta$-carotene, while other lettuce types had more $\beta$-carotene than lutein. Carotenoid concentration was higher in summer than in the fall, but was not affected by the position of the plant on the raised bed. Beta-carotene and lutein concentrations were highly correlated, suggesting that their levels could be enhanced simultaneously. Beta-carotene and lutein concentrations were both highly correlated with chlorophyll $a$, chlorophyll $b$, and total chlorophyll concentrations, suggesting that carotenoid content could be selected indirectly through chlorophyll or color measurement. These results suggest that genetic improvement of carotenoid levels in lettuce is feasible.

Carotenoids are a diverse group of lipid-soluble pigments synthesized in plants, fungi, and bacteria. Beta-carotene, a hydrocarbon carotene, and lutein, an oxygenated xanthophyll, are two nutritionally important plant-derived carotenoids. Beta-carotene is the most potent provitamin A; its deficiency can result in xerophthalmia, blindness, and premature death (Mayne, 1996). It is estimated that 124 million children worldwide are deficient in vitamin $\mathrm{A}$, and improved vitamin A nutrition could prevent 1.2 million deaths annually among children aged $1-4$ years (Humphrey et al., 1992). Lutein offers protection against the occurrence of age-related macular degeneration that is a leading cause of blindness and vision impairment among Americans 55 years or older (Seddon et al., 1994). Epidemiological studies suggest that the onset of chronic diseases such as coronary heart disease, certain cancers, and eye diseases including cataract can be reduced by high dietary intakes of carotenoid-rich foods (Johnson et al., 2000; Sies and Krinsky, 1995). Dietary intake of carotenoids like lutein, $\beta$-carotene, and lycopene has been associated with reduced risk of lung cancer (Le Marchand et al., 1993), prostate cancer (Giovannucci, 1999), and colon cancer (Slattery et al., 2000) due to their antioxidant activities.

In photosynthetic tissues, carotenoids, along with chlorophyll $a$ and $b$, function in light harvesting and play important roles in

Received for publication 9 Feb. 2005. Accepted for publication 6 Apr. 2005. We would like to thank Luther Talbert and Murshidul Hoque for their critical review and discussion of the manuscript. The technical assistance of Abby Morris, JoAnn Tanaka, Sharon Benzen, and J. Brad Murphy is greatly appreciated. Mention of a trade name, proprietary product, or vendor does not constitute an endorsement, guarantee, or warranty by the U.S. Dept. of Agriculture (USDA) and does not imply its approval to the exclusion of other products or vendors that may be suitable. This research was supported in part by grants from the Calif. Lettuce Research Board.

1Research Geneticist. E-mail address: bmou@pw.ars.usda.gov photoprotection by quenching free radicals, singlet oxygen, and other reactive species (Siefermann-Harms, 1987). The biogenesis of carotenoid takes place in chloroplasts where the carotenoid exists in photosynthetic membranes as chlorophyll-carotenoidprotein complexes (Gross, 1991). High correlations between carotenoid and chlorophyll accumulations have been reported for kale (Brassica oleracea L. var. acephala; Kopsell et al., 2004), swiss chard (Beta vulgaris L.; Ihl et al., 1994), and other crop species (Grunwald et al., 1977; Terry and Abadia, 1986).

Vegetables play an important role in human diet and nutrition. Lettuce is the most important vegetable crop produced for fresh market in the United States in terms of acreage, production, and market value [National Agricultural Statistics Service (NASS), 2005]. In the United States, $\approx 75 \%$ of lettuce is produced in California (NASS, 2005). Most carotenoids produced in lettuce are $\beta$-carotene and lutein (Hart and Scott, 1995; USDA, 2004). About two-thirds of lettuce production and consumption in the United States is of the crisphead type (NASS, 2005). Compared to leaf or romaine types, crisphead lettuce is known to have much lower $\beta$-carotene and lutein contents (USDA, 2004). However, there is very limited information about varietal differences in carotenoid content, especially within the crisphead type, as available nutrient data were mostly obtained by analyzing samples from supermarkets. Izaki et al. (1986) determined $\beta$-carotene concentration of nine lettuce cultivars grown in Japan (including one crisphead cultivar) to be between 270 and $3900 \mu \mathrm{g} / 100 \mathrm{~g}$ fresh weight. Simonne et al. (2002) evaluated carotenoid content in 17 lettuce cultivars (including two crisphead cultivars) under the warm spring conditions of the southeastern United States, and found that $\beta$-carotene levels ranged from 124 to $900 \mu \mathrm{g} / 100 \mathrm{~g}$ fresh weight while lutein varied from 387 to $2709 \mu \mathrm{g} / 100 \mathrm{~g}$. 
In addition to genetic differences, carotenoid content may also be influenced by environmental factors. Light promotes the rapid synthesis of carotenoids in etiolated plants previously grown in the dark, being constituents of the photosynthetic apparatus, and generally the optimal temperature for carotenogenesis in plants is relatively low (Gross, 1991). Bureau and Bushway (1986) found that the $\beta$-carotene content of crisphead lettuce was higher in November than in July. Carotene levels of butterhead lettuce produced by various cultivation methods ranged from 1360 to $3190 \mu \mathrm{g} / 100 \mathrm{~g}$ fresh weight in soil-grown samples and from 1810 to $2760 \mu \mathrm{g} / 100 \mathrm{~g}$ in hydroponically grown samples (Kobayashi et al., 1989). Benoit et al. (1984) found that plastic-covered and uncovered lettuce plants contained 11.0 and $16.6 \mu \mathrm{g}$ carotene per gram fresh weight, respectively. There was a positive relation between $\mathrm{N}$ fertilizer doses and carotene levels, while deficiency of $\mathrm{P}$ and $\mathrm{K}$ caused an increase in carotene content in spinach leaves (Sengewald, 1959). Bottcher (1988) found that carotene loss of head lettuce increased linearly with storage time, whereas the rate of loss was greater at higher storage temperatures.

Because plant-based foods contain numerous health-promoting phytochemicals that may act synergistically, dietary intake of carotenoids is generally viewed as more effective than the use of supplements. Despite the known benefits, efforts by public health organizations and the produce industry to increase the consumption of fruits and vegetables have met limited success due to dietary habits and cultural reasons. Over $70 \%$ of North Americans do not eat the recommended levels of fruits and vegetables, and it has been reported that consumption of vegetables would need to increase by over $300 \%$ in order to meet minimum recommendations (McNamara et al., 1999). Enhancing the nutritional levels of vegetables would improve the nutrient intake without requiring an increase in consumption. A breeding program to improve the nutritional value of lettuce must start with an assessment of the existing genetic variation in the germplasm including wild species. The objectives of this study were to assess the genetic variability in carotenoid content in different types of lettuce and wild relatives, especially in the crisphead type, to examine the relationship among $\beta$-carotene, lutein, and chlorophyll concentrations, and to evaluate the interactions of lettuce genotypes with environmental factors such as growing seasons and plant position in the field.

\section{Materials and Methods}

Experiments were conducted at the Agricultural Research Station of the USDA, Salinas, Calif. Fifty-two genotypes from the lettuce germplasm collection maintained at the station, including crisphead, green leaf, red leaf, romaine, butterhead, stem, Latin, Batavia, and primitive forms of lettuce, a chlorophyll-deficient mutant, and wild species (L. serriola, L. saligna, L. virosa) from different geographic areas, were evaluated in Summer and Fall 2003. Seeds were planted in Sunshine Plug 5 Growing Mix (Sun Gro Horticulture, Bellevue, Wash.) in plastic transplanting trays $(128$ cells, $3 \times 3 \times 5 \mathrm{~cm}$ in length $\times$ width $\times$ height $)$ in a greenhouse on 29 Apr. and 15 July for the summer and fall experiments, respectively.

Four weeks after planting, plants were transplanted in the field in a randomized complete-block design with four replications and each plot consisting of two rows of six plants each at the commercial spacing of $30 \mathrm{~cm}$ between plants and $35 \mathrm{~cm}$ between rows on a 1-m-wide double-row bed. The orientation of the rows was east-west for the summer experiment and north-south for the fall experiment. Preplant fertilizer was incorporated into the soil 1 week prior to transplanting as a combination of monoammonium phosphate, diammonium phosphate, and potassium sulfate (6N-8.8P-16.6K; Western Farm Service, Fresno, Calif.) at the rate of $336.6 \mathrm{~kg} \cdot \mathrm{ha}^{-1}$. Nitrogen was sidedressed twice as ammonium sulphate at the rate of $67.2 \mathrm{~kg} \cdot \mathrm{ha}^{-1} 2$ weeks and 5 weeks after transplanting. Sprinkler irrigation was supplied twice per week to ensure adequate soil moisture for plant growth.

For each growing season, lettuce cultivars were harvested when they reached commercial size. Wild species were harvested when plants reached full size. Two plants in the middle of the rows were harvested from each plot in the morning with one from each side of the bed. Base- and wrapper-leaves were removed from crisphead and butterhead lettuce plants at harvest. The harvested plants were put on ice, transported to the lab, and weighed. A 0.3-g sample was taken from the 7th leaf from the outside of the head for each crisphead and butterhead lettuce plant, and from a leaf in an intermediate (neither inside nor outside) position on the plant for each other types of plant. The samples were taken from the edge of the leaves to avoid major ribs and were stored on ice prior to the extraction of carotenoids. The plants were then cut into four quarters and oven-dried at $70{ }^{\circ} \mathrm{C}$ for $48 \mathrm{~h}$ before being weighed for dry weight.

Carotenoid and chlorophyll pigments were extracted and analyzed following the procedure of Norris et al. (1995) with minor modifications. The 0.3 -g lettuce sample was placed in a 1.5-mL microcentrifuge tube and ground with a pellet pestle (Kontes Glass Co., Vineland, N.J.) mounted on an electric drill in $200 \mu \mathrm{L}$ of $80 \%$ acetone. Ethyl acetate $(120 \mu \mathrm{L})$ was added, and the mixture was vortexed. Water $(140 \mu \mathrm{L})$ was added, and the mixture was vortexed and centrifuged at 15,700 $g_{\mathrm{n}}$ for $5 \mathrm{~min}$. The carotenoid and chlorophyll containing upper phase was then transferred to a fresh tube. The sample was extracted two more times by adding ethyl acetate $(120 \mu \mathrm{L})$, vortexing, centrifugation at $15,700 g_{\mathrm{n}}$ for $5 \mathrm{~min}$, and removing the upper phase. The combined upper phases were then vacuum dried in a centrifugal evaporator (SpeedVac, Savant Instruments, Farmingdale, N.Y.) and stored at $-80{ }^{\circ} \mathrm{C}$ under nitrogen until analysis. The dried extract was resuspended in $1.5 \mathrm{~mL}$ ethyl acetate, filtered through a $0.45-\mu \mathrm{m}$ syringe-driven Nylon filter (Millex-HN; Millipore Co., Bedford, Mass.), and analyzed by reverse phase high-performance liquid chromatography (HPLC). The HPLC system (Alliance, Waters Co., Milford, Mass.) consisted of a separation unit (model 2695), a $4.6 \times 10 \mathrm{~mm}$-guard cartridge (S5 ODS1), a $4.6 \times 250-\mathrm{mm}, 5-$ $\mu \mathrm{m}$ packing $\mathrm{C}_{18}$ column (S5 ODS1, Waters Spherisorb), and a photodiode array detector (model 2996). Extracts were kept in a $4{ }^{\circ} \mathrm{C}$ sample cooler before a $10-\mu \mathrm{L}$ sample was injected into a 35 -min gradient of ethyl acetate $(0 \%$ to $35 \%)$ in acetonitrilewater-triethylamine [9:1:0.01 (v/v)], at a flow rate of $1 \mathrm{~mL} \cdot \mathrm{min}^{-1}$. Carotenoid and chlorophyll pigments were identified by comparing the retention time and absorption spectra of individual peaks with the standards. The concentration of individual pigment in lettuce samples was determined using peak areas relative to the corresponding standards at $440 \mathrm{~nm}$ wavelength. Beta-carotene, lutein, chlorophyll $a$, and chlorophyll $b$ standards were obtained from Sigma Chemical Co. (St. Louis).

Data were analyzed by analysis of variance (ANOVA) using the general linear model procedure of JMP version 5 (SAS Institute, Cary, N.C.). Lettuce type and genotype were considered fixed effects, and replication and season were considered random effects. A crisphead cultivar, 'Climax', bolted before transplanting in the fall and therefore was excluded in the analyses for the fall season 
and across seasons. For comparisons between genotypes, least significant differences (LSD) were calculated with an error rate of $P=0.05$. A correlation matrix for genotypes within each season was calculated for all variables using the multivariate platform of JMP. Spearman's coefficients of rank correlation (Steel and Torrie, 1980) were calculated to test differences in rank order among the genotypes between the two growing seasons.

\section{Results and Discussion}

Beta-carotene and lutein concentrations differed significantly among lettuce types, genotypes, and seasons $(P<0.01)$. This demonstrates that there is genetic variation in carotenoid accumulation among the lettuce genotypes tested, despite the influence from environments. There was also a significant genotype $\times$ season interaction $(P<0.001)$. This suggests that the genotypes responded differently to the different environments. However, rank orders of carotenoid content did not significantly change for the genotypes from summer to fall season [Spearman's rank correlation $\left(r_{s}\right)=0.948$ and 0.930 for $\beta$-carotene and lutein concentrations, respectively. $P<0.001]$. Mercadante and RodriguezAmaya (1991) reported seasonal variation between winter and summer production in $\beta$-carotene and lutein levels between two kale cultivars grown in Brazil. Kopsell et al. (2004) also found yearly variation in $\beta$-carotene and lutein concentrations among 23 Brassica oleracea cultigens, but the interaction of year and cultigen was not significant.

Carotenoid concentration in vegetables is usually reported on a fresh weight basis in literature. On fresh weight bases, wild lettuces, including L. serriola, L. saligna, L. virosa, and primitive forms of lettuce, generally had higher carotenoid levels than cultivated lettuces (Table 1). Among the major types of cultivated lettuce, carotenoid concentration followed the order of: green leaf or romaine $>$ red leaf $>$ butterhead $>$ crisphead. The synthesis or absorption of many nutrients in plants is light dependent, and it has been demonstrated that the lower nutritional value of crisphead lettuce is largely due to the enclosure of its leaves in the head structure (Mou and Ryder, 2004). Romaine type had similar or higher carotenoid concentration than green leaf lettuce in summer, but green leaf had significantly higher carotenoid concentration than romaine in the fall (Table 1). Crisphead lettuce accumulated more lutein than $\beta$-carotene, while other lettuce types had more $\beta$-carotene than lutein.
When expressed on a dry weight basis, romaine and green leaf lettuces had significantly higher carotenoid concentration than wild lettuces (Table 1). The major difference is that the wild lettuces had much lower moisture content $(\approx 90 \%)$ than cultivated lettuces (95\% to $97 \%$ ). When expressed on fresh weight bases, therefore, the carotenoid concentration of cultivated lettuces was diluted by their high water content.

Among major cultivated lettuces, crisphead lettuce had highest head weight, followed by romaine, butterhead, green leaf, and red leaf types (Table 2). Chlorophyll $a$, chlorophyll $b$, and total chlorophyll concentrations generally followed the same rank order as carotenoid among different types of lettuce. There was also great variation in plant weight and chlorophyll concentration within the types and between the seasons. 'Merlot' and 'Ruby' both have intense red color but had higher chlorophyll concentration than the two cultivars with a mixture of green and red colors, 'Lolla Rossa' and 'Prizehead' (data not shown). This suggests that the green color of chlorophyll was masked by large amount of anthocyanin in 'Merlot' and 'Ruby'.

Although crisphead lettuce had lower carotenoid level than other lettuce types, there were significant differences among genotypes within the crisphead type whether on a fresh weight or dry weight basis (Table 3). Three modern cultivars, 'Legacy', 'Salinas 88', and 'Top Gun', consistently had higher carotenoid concentrations in summer and fall (averaging 471 and $592 \mu \mathrm{g} / 100$ $\mathrm{g}$ of $\beta$-carotene and lutein on a fresh weight basis, respectively) than other cultivars. Three older cultivars, 'Great Lakes', 'Green Lake', and 'Imperial 44', had the lowest carotenoid concentrations in both seasons (averaging 168 and $182 \mu \mathrm{g} / 100 \mathrm{~g}$ of $\beta$-carotene and lutein on a fresh weight basis, respectively). These results attest to the achievements of modern lettuce breeding, although nutritional improvement has not received great attention in the past (Ryder, 1986).

Two butterhead cultivars of "Bibb" type ('Bibb' and 'Buttercrunch') had significantly higher carotenoid concentration in both seasons (averaging 2434 and $2179 \mu \mathrm{g} / 100 \mathrm{~g}$ of $\beta$-carotene and lutein on a fresh weight basis, respectively) than three butterhead cultivars of "Boston" type ('Dark Green Boston', 'Dynamite', and 'Epic'; averaging 832 and $746 \mu \mathrm{g} / 100 \mathrm{~g}$ of $\beta$-carotene and lutein on a fresh weight basis, respectively; Table 3 ). The top of the head for "Boston" type of lettuce is closed, while the top of "Bibb" type of lettuce is more open. The semi-open head of "Bibb" type allows easier penetration of sunlight into the head,

Table 1. Means of moisture, $\beta$-carotene and lutein concentration, expressed on fresh weight and dry weight bases ( $\mu$ g per unit leaf wt), for different types of lettuce grown in the field in Salinas, Calif., in Summer and Fall 2003. ${ }^{\mathrm{z}}$

\begin{tabular}{|c|c|c|c|c|c|c|c|c|c|c|c|}
\hline \multirow[b]{3}{*}{ Type $^{y}$} & \multirow{3}{*}{$\begin{array}{c}\text { No. of } \\
\text { genotype }\end{array}$} & \multirow{2}{*}{\multicolumn{2}{|c|}{ Moisture (\%) }} & \multicolumn{4}{|c|}{ Beta-carotene } & \multicolumn{4}{|c|}{ Lutein } \\
\hline & & & & \multicolumn{2}{|c|}{ Fresh wt $(\mu \mathrm{g} / 100 \mathrm{~g})$} & \multicolumn{2}{|c|}{ Dry wt $\left(\mu g \cdot g^{-1}\right)$} & \multicolumn{2}{|c|}{ Fresh wt $(\mu \mathrm{g} / 100 \mathrm{~g})$} & \multicolumn{2}{|c|}{ Dry wt $\left(\mu g \cdot g^{-1}\right)$} \\
\hline & & Summer & Fall & Summer & Fall & Summer & Fall & Summer & Fall & Summer & Fall \\
\hline Crisphead & 22 & $96.7 \mathrm{a}$ & $97.0 \mathrm{a}$ & $328 \mathrm{f}$ & $319 \mathrm{~h}$ & $102 \mathrm{f}$ & $108 \mathrm{f}$ & $416 \mathrm{f}$ & $372 \mathrm{i}$ & $131 \mathrm{e}$ & $131 \mathrm{f}$ \\
\hline Butterhead & 5 & $96.5 \mathrm{ab}$ & $96.2 \mathrm{~b}$ & 1418 e & $1527 \mathrm{f}$ & $410 \mathrm{e}$ & $415 \mathrm{~d}$ & 1303 e & $1335 \mathrm{~g}$ & $382 \mathrm{~d}$ & $367 \mathrm{e}$ \\
\hline Romaine & 5 & $95.6 \mathrm{~cd}$ & $95.4 \mathrm{c}$ & $4029 \mathrm{~b}$ & $3228 \mathrm{~d}$ & $954 \mathrm{a}$ & 749 a & $3985 \mathrm{~b}$ & $2868 \mathrm{~d}$ & $946 \mathrm{a}$ & $654 \mathrm{ab}$ \\
\hline Green leaf & 5 & $94.5 \mathrm{e}$ & $94.7 \mathrm{e}$ & $4038 \mathrm{~b}$ & $3860 \mathrm{c}$ & $748 \mathrm{~b}$ & $714 \mathrm{a}$ & $3338 \mathrm{c}$ & $3106 \mathrm{c}$ & $613 \mathrm{~b}$ & $574 \mathrm{c}$ \\
\hline Red leaf & 4 & $95.3 \mathrm{~d}$ & $95.4 \mathrm{~cd}$ & $2464 d$ & $2231 \mathrm{e}$ & $545 \mathrm{~d}$ & $494 \mathrm{bc}$ & $2138 d$ & $1961 \mathrm{f}$ & $473 \mathrm{c}$ & $430 \mathrm{~d}$ \\
\hline Batavia & 1 & $96.5 \mathrm{ab}$ & $94.9 \mathrm{de}$ & $1364 \mathrm{e}$ & $1054 \mathrm{~g}$ & $406 \mathrm{e}$ & 204 e & $1021 \mathrm{e}$ & $938 \mathrm{~h}$ & $346 \mathrm{~d}$ & $178 \mathrm{f}$ \\
\hline Latin & 1 & $96.1 \mathrm{bc}$ & $96.0 \mathrm{~b}$ & $3121 \mathrm{c}$ & $2323 \mathrm{e}$ & $819 \mathrm{~b}$ & $568 \mathrm{~b}$ & $2274 d$ & $2178 \mathrm{e}$ & $620 \mathrm{~b}$ & $596 \mathrm{bc}$ \\
\hline Stem & 1 & $94.2 \mathrm{e}$ & $94.4 \mathrm{e}$ & $4237 \mathrm{~b}$ & $4136 \mathrm{~b}$ & $715 \mathrm{~b}$ & $708 \mathrm{a}$ & $3629 \mathrm{c}$ & $4316 a$ & $636 \mathrm{~b}$ & $700 \mathrm{a}$ \\
\hline Wild & 7 & $88.9 \mathrm{f}$ & $90.3 \mathrm{f}$ & $6609 a$ & 4472 a & $607 \mathrm{c}$ & $472 \mathrm{c}$ & $5578 \mathrm{a}$ & $3707 \mathrm{~b}$ & $510 \mathrm{c}$ & $397 \mathrm{de}$ \\
\hline Chl deficient & 1 & $96.9 \mathrm{a}$ & $96.6 \mathrm{ab}$ & $249 \mathrm{f}$ & $161 \mathrm{~h}$ & $83 \mathrm{f}$ & $41 \mathrm{f}$ & $305 \mathrm{f}$ & 204 i & $106 \mathrm{e}$ & $50 \mathrm{~g}$ \\
\hline Mean & & 95.2 & 95.4 & 2302 & 1915 & 409 & 362 & 2060 & 1682 & 380 & 329 \\
\hline
\end{tabular}

${ }^{\mathrm{z}}$ Means in the same column followed by different letters indicate significant differences at $P<0.05$.

${ }^{y}$ Wild type includes L. serriola, L. saligna, L. virosa, and primitive forms of lettuce. Chl, chlorophyll. 
Table 2. Means of plant weight, chlorophyll (Chl) $a$ and $b$, and total chlorophyll ( $\mathrm{Chl} a+\mathrm{Chl} b$ ) concentration on a fresh weight basis ( $\mu \mathrm{g}$ per $100 \mathrm{~g}$ leaf) for different lettuce types grown in the field in Salinas, Calif., in Summer and Fall 2003.

\begin{tabular}{|c|c|c|c|c|c|c|c|c|}
\hline \multirow[b]{2}{*}{ Type $^{y}$} & \multicolumn{2}{|c|}{ Plant wt (g) } & \multicolumn{2}{|c|}{ Chl $a(\mu \mathrm{g} / 100 \mathrm{~g})$} & \multicolumn{2}{|c|}{ Chl $b(\mu \mathrm{g} / 100 \mathrm{~g})$} & \multicolumn{2}{|c|}{ Total Chl $(\mu \mathrm{g} / 100 \mathrm{~g})$} \\
\hline & Summer & Fall & Summer & Fall & Summer & Fall & Summer & Fall \\
\hline Crisphead & $1037 \mathrm{a}$ & $829 \mathrm{a}$ & $2936 \mathrm{~g}$ & $4146 \mathrm{~g}$ & $1760 \mathrm{~g}$ & 2036 ef & $4695 \mathrm{f}$ & $6182 \mathrm{~h}$ \\
\hline Butterhead & $406 \mathrm{c}$ & $312 \mathrm{c}$ & $16459 \mathrm{f}$ & $21410 \mathrm{e}$ & $6376 \mathrm{e}$ & $6957 \mathrm{~d}$ & $22873 \mathrm{e}$ & $28367 \mathrm{f}$ \\
\hline Romaine & $650 \mathrm{~b}$ & $508 \mathrm{~b}$ & $45076 \mathrm{~cd}$ & $54263 \mathrm{~b}$ & $26473 \mathrm{~b}$ & $19445 \mathrm{a}$ & $71549 \mathrm{~b}$ & $73708 \mathrm{~b}$ \\
\hline Green leaf & $273 \mathrm{~d}$ & $304 \mathrm{c}$ & $49248 \mathrm{bc}$ & $51846 \mathrm{~b}$ & $17002 \mathrm{c}$ & $14873 \mathrm{~b}$ & $66249 \mathrm{~b}$ & $66719 \mathrm{c}$ \\
\hline Red leaf & $291 \mathrm{~d}$ & $228 \mathrm{~d}$ & $33691 \mathrm{e}$ & $27761 \mathrm{~d}$ & $9806 \mathrm{~d}$ & $8025 \mathrm{~d}$ & $43497 \mathrm{~d}$ & $35786 \mathrm{e}$ \\
\hline Batavia & $630 \mathrm{~b}$ & $472 \mathrm{~b}$ & $17414 \mathrm{f}$ & $13203 \mathrm{f}$ & $5373 \mathrm{ef}$ & $3727 \mathrm{e}$ & $22787 \mathrm{e}$ & $16931 \mathrm{~g}$ \\
\hline Latin & $332 \mathrm{~cd}$ & $233 \mathrm{~cd}$ & $40832 \mathrm{de}$ & $37728 \mathrm{c}$ & $13305 \mathrm{~cd}$ & $11130 \mathrm{c}$ & $54138 \mathrm{c}$ & $48857 \mathrm{~d}$ \\
\hline Stem & $210 \mathrm{de}$ & $307 \mathrm{~cd}$ & $52703 \mathrm{~b}$ & $67655 \mathrm{a}$ & $14881 \mathrm{c}$ & 19779 a & $67584 \mathrm{~b}$ & $87435 \mathrm{a}$ \\
\hline Wild & $94 \mathrm{e}$ & $87 \mathrm{e}$ & $78414 \mathrm{a}$ & $65139 \mathrm{a}$ & $30865 \mathrm{a}$ & $18878 \mathrm{a}$ & 109279 a & 84017 a \\
\hline Chl deficient & $647 \mathrm{~b}$ & $560 \mathrm{~b}$ & $2084 \mathrm{~g}$ & $1513 \mathrm{~g}$ & $1129 \mathrm{fg}$ & $720 \mathrm{f}$ & $3212 \mathrm{f}$ & $2233 \mathrm{~h}$ \\
\hline Mean & 636 & 512 & 27335 & 27682 & 11114 & 8799 & 38498 & 36481 \\
\hline
\end{tabular}

${ }^{7}$ Means in the same column followed by different letters indicate significant differences at $P<0.05$.

${ }^{y}$ Wild type includes $L$. serriola, L. saligna, L. virosa, and primitive forms of lettuce.

Table 3. Means of moisture, $\beta$-carotene and lutein concentration, expressed on fresh weight and dry weight bases ( $\mu g$ per unit leaf wt), for 52 lettuce genotypes grown in the field in Salinas, Calif., in Summer and Fall 2003.

\begin{tabular}{|c|c|c|c|c|c|c|c|c|c|c|c|}
\hline \multirow[b]{3}{*}{ Genotype } & \multirow[b]{3}{*}{ Type $^{z}$} & \multirow{2}{*}{\multicolumn{2}{|c|}{ Moisture (\%) }} & \multicolumn{4}{|c|}{ Beta-carotene } & \multicolumn{4}{|c|}{ Lutein } \\
\hline & & & & \multicolumn{2}{|c|}{ Fresh wt $(\mu \mathrm{g} / 100 \mathrm{~g})$} & \multicolumn{2}{|c|}{ Dry wt $\left(\mu \mathrm{g} \cdot \mathrm{g}^{-1}\right)$} & \multicolumn{2}{|c|}{ Fresh wt $(\mu \mathrm{g} / 100 \mathrm{~g})$} & \multicolumn{2}{|c|}{ Dry wt $\left(\mu \mathrm{g} \cdot \mathrm{g}^{-1}\right)$} \\
\hline & & Summer & Fall & Summer & Fall & Summer & Fall & Summer & Fall & Summer & Fall \\
\hline Bronco & Crisphead & 97.2 & 96.9 & 340 & 316 & 140 & 101 & 485 & 393 & 175 & 128 \\
\hline Calmar & Crisphead & 96.2 & 97.6 & 318 & 262 & 87 & 101 & 346 & 299 & 89 & 136 \\
\hline Climax & Crisphead & 97.5 & ---- & 398 & ---- & 177 & ---- & 478 & ---- & 212 & ---- \\
\hline Empire & Crisphead & 96.5 & 98.2 & 260 & 221 & 69 & 124 & 347 & 227 & 99 & 123 \\
\hline Francisco & Crisphead & 96.5 & 97.0 & 222 & 248 & 74 & 85 & 280 & 330 & 99 & 112 \\
\hline Glacier & Crisphead & 96.4 & 97.6 & 538 & 273 & 132 & 117 & 498 & 338 & 117 & 159 \\
\hline Great Lakes & Crisphead & 97.1 & 96.5 & 167 & 181 & 47 & 50 & 159 & 176 & 45 & 46 \\
\hline Green Lake & Crisphead & 97.1 & 97.3 & 203 & 179 & 82 & 72 & 226 & 208 & 81 & 83 \\
\hline Ice Cube & Crisphead & 96.2 & 96.0 & 311 & 347 & 69 & 84 & 548 & 467 & 132 & 117 \\
\hline Imperial 44 & Crisphead & 97.3 & 97.3 & 105 & 175 & 42 & 78 & 129 & 192 & 45 & 95 \\
\hline King Crown & Crisphead & 95.8 & 97.5 & 311 & 301 & 78 & 122 & 306 & 350 & 76 & 147 \\
\hline Legacy & Crisphead & 97.5 & 96.5 & 477 & 408 & 201 & 109 & 644 & 449 & 297 & 118 \\
\hline Mohawk & Crisphead & 96.0 & 96.3 & 236 & 316 & 63 & 99 & 295 & 339 & 82 & 110 \\
\hline Monterey & Crisphead & 96.2 & 96.3 & 340 & 379 & 65 & 94 & 304 & 375 & 69 & 97 \\
\hline Niner & Crisphead & 97.0 & 98.0 & 217 & 245 & 80 & 88 & 294 & 290 & 109 & 145 \\
\hline Salinas 88 & Crisphead & 96.4 & 96.9 & 528 & 509 & 154 & 161 & 662 & 526 & 185 & 161 \\
\hline Sniper & Crisphead & 96.6 & 97.2 & 402 & 350 & 113 & 135 & 563 & 407 & 159 & 151 \\
\hline Thompson & Crisphead & 97.1 & 97.1 & 271 & 230 & 97 & 81 & 416 & 291 & 132 & 102 \\
\hline Tiber & Crisphead & 97.2 & 97.3 & 532 & 342 & 206 & 127 & 710 & 398 & 279 & 159 \\
\hline Top Gun & Crisphead & 96.4 & 97.0 & 458 & 444 & 102 & 143 & 688 & 582 & 166 & 196 \\
\hline Vanguard 75 & Crisphead & 95.6 & 96.4 & 227 & 520 & 41 & 134 & 302 & 639 & 58 & 187 \\
\hline Yuma & Crisphead & 97.0 & 96.6 & 355 & 463 & 129 & 166 & 466 & 543 & 178 & 185 \\
\hline Bibb & Butterhead & 96.5 & 96.4 & 2819 & 2847 & 751 & 802 & 2544 & 2394 & 735 & 682 \\
\hline Buttercrunch & Butterhead & 96.6 & 96.1 & 2122 & 1946 & 687 & 505 & 2016 & 1762 & 641 & 448 \\
\hline Dark Green Boston & Butterhead & 97.0 & 95.8 & 731 & 851 & 194 & 191 & 681 & 724 & 166 & 176 \\
\hline Dynamite & Butterhead & 96.6 & 97.2 & 650 & 630 & 205 & 217 & 538 & 572 & 154 & 222 \\
\hline Epic & Butterhead & 95.9 & 95.5 & 768 & 1361 & 212 & 362 & 737 & 1226 & 217 & 308 \\
\hline Darkland & Romaine & 94.8 & 96.4 & 5242 & 3690 & 1000 & 1086 & 5426 & 3304 & 1111 & 967 \\
\hline Heart's Delight & Romaine & 95.3 & 95.3 & 2379 & 1427 & 550 & 340 & 2627 & 1608 & 622 & 337 \\
\hline Parris Island & Romaine & 95.3 & 95.1 & 4208 & 3492 & 953 & 704 & 4095 & 2780 & 876 & 571 \\
\hline Tall Guzmaine & Romaine & 96.5 & 95.4 & 3573 & 3818 & 1022 & 836 & 3142 & 3329 & 900 & 722 \\
\hline Valmaine & Romaine & 96.3 & 95.0 & 4741 & 3711 & 1245 & 778 & 4633 & 3317 & 1220 & 674 \\
\hline Grand Rapids & Green leaf & 94.3 & 95.1 & 2927 & 2272 & 565 & 436 & 2200 & 1821 & 405 & 348 \\
\hline Greengo & Green leaf & 94.1 & 95.3 & 5088 & 5184 & 831 & 1044 & 4413 & 4366 & 746 & 877 \\
\hline PI 206963 & Green leaf & 92.6 & 93.7 & 5693 & 5508 & 752 & 915 & 4598 & 4458 & 615 & 718 \\
\hline Salad Bowl & Green leaf & 95.4 & 93.8 & 2873 & 2907 & 668 & 460 & 2195 & 2007 & 470 & 329 \\
\hline Waldmann's Green & Green leaf & 96.0 & 95.3 & 3609 & 3426 & 922 & 715 & 3286 & 2877 & 829 & 598 \\
\hline
\end{tabular}


Table 3. Continued.

\begin{tabular}{|c|c|c|c|c|c|c|c|c|c|c|c|}
\hline \multirow[b]{3}{*}{ Genotype } & \multirow[b]{3}{*}{ Type $^{z}$} & & & \multicolumn{4}{|c|}{ Beta-carotene } & \multicolumn{4}{|c|}{ Lutein } \\
\hline & & \multicolumn{2}{|c|}{ Moisture (\%) } & \multicolumn{2}{|c|}{ Fresh wt $(\mu \mathrm{g} / 100 \mathrm{~g})$} & \multicolumn{2}{|c|}{ Dry wt $\left(\mu g \cdot g^{-1}\right)$} & \multicolumn{2}{|c|}{ Fresh wt $(\mu \mathrm{g} / 100 \mathrm{~g})$} & \multicolumn{2}{|c|}{ Dry wt $\left(\mu \mathrm{g} \cdot \mathrm{g}^{-1}\right)$} \\
\hline & & Summer & Fall & Summer & Fall & Summer & Fall & Summer & Fall & Summer & Fall \\
\hline Lolla Rossa & Red leaf & 95.1 & 95.7 & 2010 & 1200 & 421 & 305 & 1489 & 1144 & 325 & 289 \\
\hline Merlot & Red leaf & 94.7 & 94.8 & 3337 & 2961 & 646 & 563 & 3000 & 2456 & 592 & 456 \\
\hline Prizehead & Red leaf & 96.2 & 96.1 & 2365 & 2090 & 608 & 572 & 2239 & 1977 & 587 & 523 \\
\hline Ruby & Red leaf & 95.2 & 95.0 & 2141 & 2673 & 504 & 535 & 1823 & 2268 & 389 & 453 \\
\hline Iceberg & Batavia & 96.5 & 94.9 & 1364 & 1054 & 406 & 204 & 1021 & 938 & 346 & 178 \\
\hline Little Gem & Latin & 96.1 & 96.0 & 3121 & 2323 & 819 & 568 & 2274 & 2178 & 620 & 596 \\
\hline Da Ye Wo Sun & Stem & 94.2 & 94.4 & 4237 & 4136 & 715 & 708 & 3629 & 4316 & 636 & 700 \\
\hline PI 251247 & Primitive & 90.0 & 90.8 & 9090 & 3437 & 885 & 397 & 7586 & 2536 & 737 & 301 \\
\hline PI 490999 & L. saligna & 89.8 & 91.2 & 5383 & 5770 & 533 & 671 & 4502 & 5763 & 437 & 683 \\
\hline PI 509525 & L. saligna & 88.7 & 90.0 & 5787 & 3049 & 506 & 308 & 5072 & 2255 & 420 & 232 \\
\hline PI 491181 & L. serriola & 89.8 & 88.8 & 8264 & 4981 & 798 & 422 & 7486 & 3638 & 778 & 317 \\
\hline PI 491239 & L. serriola & 89.9 & 91.5 & 5293 & 5295 & 538 & 626 & 4724 & 3739 & 454 & 433 \\
\hline PI 273597 & L. virosa & 87.5 & 89.9 & 5415 & 4213 & 441 & 429 & 4391 & 4035 & 338 & 401 \\
\hline PI 274375 & L. virosa & 86.9 & 89.9 & 7030 & 4561 & 550 & 450 & 5287 & 3980 & 408 & 411 \\
\hline 801277-1 & Chl deficient & 96.9 & 96.6 & 249 & 161 & 83 & 41 & 305 & 204 & 106 & 50 \\
\hline Mean & & 95.2 & 95.4 & 2302 & 1915 & 409 & 362 & 2060 & 1682 & 380 & 329 \\
\hline $\operatorname{LSD}_{0.05}{ }^{\mathrm{y}}$ & & 0.6 & 0.6 & 323 & 223 & 99 & 93 & 318 & 269 & 82 & 96 \\
\hline
\end{tabular}

${ }^{\mathrm{z}}$ Chl, chlorophyll.

${ }^{\mathrm{y}}$ Least significant differences at $P<0.05$.

Table 4. Mean values of carotenoids (expressed on a fresh weight basis) and plant weight as affected by season and plant position on bed for lettuce genotypes grown in the field in Salinas, Calif., in Summer and Fall 2003. ${ }^{\mathrm{z}}$

\begin{tabular}{lcccc}
\hline Season & $\begin{array}{c}\text { Bed } \\
\text { position }^{\mathrm{y}}\end{array}$ & $\begin{array}{c}\text { Beta-carotene } \\
(\mu \mathrm{g} / 100 \mathrm{~g})\end{array}$ & $\begin{array}{c}\text { Lutein } \\
(\mu \mathrm{g} / 100 \mathrm{~g})\end{array}$ & $\begin{array}{c}\text { Plant wt } \\
(\mathrm{g})\end{array}$ \\
\hline Summer & South & $1901 \mathrm{a}$ & $1742 \mathrm{a}$ & $689 \mathrm{a}$ \\
Summer & North & $1907 \mathrm{a}$ & $1729 \mathrm{a}$ & $671 \mathrm{a}$ \\
Fall & West & $1848 \mathrm{~b}$ & $1622 \mathrm{~b}$ & $542 \mathrm{~b}$ \\
Fall & East & $1841 \mathrm{~b}$ & $1630 \mathrm{~b}$ & $495 \mathrm{c}$ \\
\hline
\end{tabular}

${ }^{z}$ PI 206963, PI 251247, PI 490999, and PI 491181 were excluded from analysis as bed position data for these genotypes were not collected. Means in the same column followed by different letters indicate significant differences at $P<0.05$.

${ }^{y}$ Indicating plant samples were harvested from which side of the double row beds.

which probably contributed to its higher carotenoid content.

A romaine cultivar, 'Heart's Delight', had much lower carotenoid level in both seasons (averaging 1903 and $2118 \mu \mathrm{g} / 100 \mathrm{~g}$ of $\beta$-carotene and lutein on a fresh weight basis, respectively) than other four romaine cultivars (averaging 4059 and $3753 \mu \mathrm{g} / 100$ $\mathrm{g}$ of $\beta$-carotene and lutein on a fresh weight basis, respectively; Table 3). 'Heart's Delight' is a cultivar for romaine heart production and forms a closed head, while other romaine cultivars have open heads. The closed head obstructs the penetration of sunlight, probably leading to its lower carotenoid content.

Significant differences in carotenoid concentration were also found among genotypes within green leaf and red leaf types (Table 3). PI 206963 and 'Greengo' had higher carotenoid levels than other leaf lettuces in both seasons. Simonne et al. (2002) also reported that 'Greengo' was the highest in $\beta$-carotene among 17 lettuce cultivars tested. 'Merlot' had the highest carotenoid concentration among red leaf cultivars.

Along with genetic variability, there also appears to be an environmental influence on carotenoid accumulation in lettuce. Carotenoid concentration and plant weight were significantly higher in summer than in the fall (Table 4). Some wild, primi- tive, and romaine lettuces especially showed large reductions in carotenoid level in the fall (Table 3). The summer experiment was harvested in July when average solar radiation and air temperature were $294 \mathrm{~W} \cdot \mathrm{m}^{-2}$ and $16.2^{\circ} \mathrm{C}$, while the fall experiment was harvested in October when average solar radiation and air temperature were $173 \mathrm{~W} \cdot \mathrm{m}^{-2}$ and $15.1^{\circ} \mathrm{C}$, respectively [California Irrigation Management Information System (CIMIS), 2003]. As the synthesis of carotenoids is light dependent, the reduced solar radiation in the fall may have contributed to the lower carotenoid content in lettuce. There was also an overall reduction in chlorophyll $b$ and total chlorophyll concentrations from summer to fall, although there was an increase in chlorophyll $a$ and total chlorophyll levels in the fall for crisphead, butterhead, romaine, green leaf, and stem lettuces (Table 2). These results suggest that environmental manipulations during production, in conjunction with the selection of cultivars, may be necessary to optimize the carotenoid levels of lettuce crops.

It is a standard practice to grow lettuce on double-row raised beds in California. There was no difference in carotenoid concentration whether plant samples were from the north or south side of the bed in summer or from the east or west side of the 
Table 5. Correlation coefficients $(r)$ between traits calculated from the means of 52 lettuce genotypes grown in Salinas, Calif. over two seasons in 2003. The values above the diagonal (----) lines are from the summer season, and the values below the diagonal (----) lines are from the fall season. All coefficients are significant at $P<0.01$.

\begin{tabular}{|c|c|c|c|c|c|c|c|c|c|}
\hline Traits $^{z}$ & $\begin{array}{c}\text { Plant } \\
\text { wt }\end{array}$ & $\begin{array}{c}\text { Moisture } \\
(\%)\end{array}$ & $\begin{array}{c}\text { Beta- } \\
\text { carotene } \\
\text { (fresh wt) }\end{array}$ & $\begin{array}{l}\text { Lutein } \\
\text { (fresh wt) }\end{array}$ & Chl $a$ & Chl $b$ & Total Chl & $\begin{array}{c}\text { Beta- } \\
\text { carotene } \\
\text { (dry wt) }\end{array}$ & $\begin{array}{c}\text { Lutein } \\
\text { (dry wt) }\end{array}$ \\
\hline Plant wt & ---- & 0.677 & -0.744 & -0.705 & -0.770 & -0.587 & -0.741 & -0.622 & -0.516 \\
\hline Moisture (\%) & 0.773 & ---- & -0.826 & -0.789 & -0.838 & -0.684 & -0.821 & -0.381 & -0.299 \\
\hline Beta-carotene (fresh wt) & -0.746 & -0.771 & ---- & 0.992 & 0.948 & 0.943 & 0.984 & 0.800 & 0.746 \\
\hline Lutein (fresh wt) & -0.722 & -0.735 & 0.985 & ---- & 0.937 & 0.962 & 0.982 & 0.818 & 0.788 \\
\hline Chl $a$ & -0.684 & -0.725 & 0.985 & 0.986 & ---- & 0.828 & 0.983 & 0.777 & 0.717 \\
\hline Chl $b$ & -0.632 & -0.677 & 0.962 & 0.964 & 0.987 & ---- & 0.917 & 0.794 & 0.783 \\
\hline Total Chl & -0.674 & -0.716 & 0.982 & 0.983 & 0.999 & 0.992 & ---- & 0.813 & 0.767 \\
\hline$\beta$-Carotene (dry wt) & -0.582 & -0.396 & 0.863 & 0.865 & 0.866 & 0.887 & 0.873 & ---- & 0.978 \\
\hline Lutein (dry wt) & -0.536 & -0.339 & 0.826 & 0.854 & 0.846 & 0.869 & 0.853 & 0.986 & ---- \\
\hline
\end{tabular}

$\bar{z}$ (fresh wt) and (dry wt), carotenoid concentrations expressed on a fresh weight and dry weight basis, respectively; Chl = chlorophyll concentration expressed on a fresh weight basis.

bed in the fall (Table 4). However, plants on the west side of the bed had significantly higher weight than plants on the east side of the bed in the fall. That was probably due to the fact that it was often foggy in the morning in the fall and plants on the west side of the bed received more sunlight in the afternoon.

During each season, $\beta$-carotene and lutein concentrations, whether on a fresh weight or dry weight basis, were highly correlated (Table 5). This is good news for lettuce breeders as selection for higher levels of one carotenoid would likely lead to the increase of the other carotenoid. Plant weight was negatively correlated with $\beta$-carotene, lutein, and chlorophyll concentrations, probably because crisphead cultivars tend to have high plant weight and low pigment levels (Tables 1 and 2). Likewise, there were highly negative correlations between moisture content and pigment levels on a fresh weight basis, partly because crisphead lettuce generally had high moisture content and low pigment accumulation (Tables 1 and 2). Beta-carotene and lutein concentrations were highly correlated with chlorophyll $a$, chlorophyll $b$, and total chlorophyll concentrations in both seasons on a fresh weight basis (Table 5). On a dry weight basis, $\beta$-carotene and lutein concentrations were also highly correlated with chlorophyll $a$, chlorophyll $b$, and total chlorophyll concentrations in both seasons, with correlation coefficients ranging from 0.93 to 0.99 . This suggests that carotenoid levels in lettuce may be selected indirectly by selecting for chlorophyll concentration or green color, which is much easier to do than carotenoid analysis and may therefore be more suitable for lettuce breeders who usually have a large population of plants to screen. Indeed, 'Waldmann's Green' is a green leaf lettuce selected from 'Grand Rapids' and had higher carotenoid level than 'Grand Rapids' that has yellow green leaves (Table 3). 801277-1 is a chlorophyll deficient mutant of lettuce with a recessive gene ( $c d-3$; Ryder, 1996) and yellow leaves, and was low in both chlorophylls and carotenoids in both seasons (Tables 2 and 3). Similar relationships between carotenoids and chlorophylls have been reported for other leafy vegetables like kale (Kopsell et al., 2004) and swiss chard (Ihl et al., 1994).

The major product from agricultural production is food that is fundamental to human life and health. Consumers have become more demanding for safe and nutritious foods that improve physical performance, reduce risks of diseases, and increase the life span. Because of the reported health benefits of carotenoids in fruits and vegetables, there is great interest in increasing the carotenoid levels in lettuce that is the most consumed fresh vegetable in the United States. In this study, we found a wide range of genetic variability in carotenoid concentration in different types of lettuce and wild species, including the crisphead type. It may therefore be possible to increase the nutritional value of different types of cultivated lettuce through crosses with same or different types of lettuce with high levels of carotenoid and subsequent selection. Attention should be paid to moisture percentage of the plant, as the higher carotenoid concentration in wild lettuces may not be transferable to cultivated lettuces that have higher water content. Coupled with the potential use of chlorophyll content or green color as selection markers, genetic improvement of carotenoid content in lettuce seems feasible.

\section{Literature Cited}

Benoit, F., C. Ceustermans, J. Rouchaud, and K. Vlassak. 1984. Influence of direct plastic covering upon the quality of carrots and lettuce. Acta Hort. 154:321-328.

Bottcher, H. 1988. Quality changes during the storage of head lettuce (Lactuca sativa L. var. capitata L.). Part 2. Nutritional value. Nahrung 32:27-36.

Bureau, J.L. and R.J. Bushway. 1986. HPLC determination of carotenoids in fruits and vegetables in the United States. J. Food Sci. 51:128-130.

California Irrigation Management Information System. 2003. California Irrigation Management Information System monthly report. Monterey Bay - Salinas South - \#89. 27 Mar. 2005. <http://wwwcimis.water. ca.gov/cimis/data.jsp>.

Giovannucci, E. 1999. Tomatoes, tomato-based products, lycopene and cancer: Review of the epidemiologic literature. J. Natl. Cancer Inst. 91:317-331.

Gross, J. 1991. Pigments in vegetables: Chlorophylls and carotenoids. AVI, Westport, Conn.

Grunwald, C., J.L. Sims, and S.J. Sheen. 1977. Effects of nitrogen fertilization and stalk position on chlorophyll, carotenoids, and certain lipids of three tobacco genotypes. Can. J. Plant Sci. 57:525-535.

Hart, D.J. and K.J. Scott. 1995. Development and evaluation of an HPLC method for the analysis of carotenoids in foods, and the measurement of the carotenoid content of vegetables and fruits commonly consumed in the UK. Food Chem. 54:101-111.

Humphrey, J.H., K.P. West, Jr., and A. Sommer. 1992. Vitamin A deficiency and attributable mortality among under 5 year olds. World Health Organization Bul. 70:225-232.

Ihl, M., C. Shene, E. Scheuermann, and V. Bifani. 1994. Correlation for pigment content through color determination using tristimulus values in a green leafy vegetable, Swiss chard. J. Sci. Food Agr. 66:527-531.

Izaki, Y., K. Yoshida, K. Hidaka, and K. Toda. 1986. Chlorophylls, carotenes and tocopherols in green vegetables and their relationships. J. Jpn. Soc. Nutr. Food Sci. 39:485-493. 
Johnson, E.J., B.R. Hammond, K.J. Yeum, J. Qin, X.D. Wang, C. Castaneda, D.M. Snodderly, and R.M. Russell. 2000. Relation among serum and tissue concentrations of lutein and zeaxanthin and macular pigment density. Amer. J. Clinical Nutr. 71:1555-1562.

Kobayashi, K., A. Tsurumizu, M. Toyoda, and Y. Sayto. 1989. Contents of chlorophylls, $\beta$-carotene and pesticide residues in butter head lettuce produced by various cultivation methods. Nippon Shokuhin Kogyo Gakkaishi 36:676-681.

Kopsell, D.A., D.E. Kopsell, M.G. Lefsrud, J. Curran-Celentano, and L.E. Dukach. 2004. Variation in lutein, $\beta$-carotene, and chlorophyll concentrations among Brassica oleracea cultigens and seasons. HortScience 39:361-364.

Le Marchand,L., J.H. Hankin, L.N. Kolonel, G.R. Beecher,L.R. Wilkene, and L.P. Zhao. 1993. Intake of specific carotenoids and lung cancer risk. Cancer Epidemiol. Biomarkers Prevention 2:183-187.

Mayne, S.T. 1996. $\beta$-Carotene, carotenoids and disease prevention in humans. FASEB J. 10:690-701.

McNamara,P.E., C.K. Ranney, L.S. Kantor, and S.M. Krebs-Smith. 1999. The gap between food intakes and the pyramid recommendations: Measurement and food system ramifications. Food Policy 24:117-134.

Mercadante, A.Z. and D.B. Rodriguez-Amaya. 1991. Carotenoid composition of a leafy vegetable in relation to some agricultural variables. J. Agr. Food Chem. 39(6):1094-1097.

Mou, B. and E.J. Ryder. 2004. Relationship between the nutritional value and the head structure of lettuce. Acta Hort. 637: 361-367.

National Agricultural Statistics Service. 2005. Vegetables 2004 summary. NASS, U.S. Dept. of Agr. 27 Mar. 2005. <http://usda.mannlib.cornell. edu/reports/nassr/fruit/pvg-bban/vgan0105.txt>.

Norris, S.R., T.R. Barrette, and D. DellaPenna. 1995. Genetic dissection of carotenoid synthesis in Arabidopsis defines plastoquinone as an essential component of phytoene desaturation. Plant Cell 7:2139-2149.
Ryder, E.J. 1986. Lettuce breeding, p. 433-474. In: M.J. Bassett (ed.). Breeding vegetable crops. AVI, Westport, Conn.

Ryder, E.J. 1996. Inheritance of chlorophyll deficiency traits in lettuce. J. Hered. 87:314-318.

Seddon, J.M., U.A. Ajani, R.D. Speruto, R. Hiller, N. Blair, T.C. Burton, M.D. Farber, E.S. Gragoudas, J. Haller, D.T. Miller, L.A. Yannuzzi, and W. Willett. 1994. Dietary carotenoids, vitamin A, vitamin C and vitamin $\mathrm{E}$ and advanced age-related macular degeneration. J. Amer. Medical Assn. 272:1413-1420.

Sengewald, E. 1959. Untersuchungen über den Einfluss der Düngung auf den Carotin- und Vitamin-C-Gehalt von Spinat (Spinacia oleracea L.) unter Berücksichtigung der Entwicklung. Nahrung 3:453-456.

Siefermann-Harms, D. 1987. The light-harvesting and protective functions of carotenoids in photosynthetic membranes. Physiol. Plant. 69:561-568.

Sies, H. and N.I. Krinsky. 1995. Antioxidant vitamins and $\beta$-carotene in disease prevention. Amer. J. Clinical Nutr. 62:1299-1300.

Simonne, A., E. Simonne, R. Eitenmiller, and C.H. Coker. 2002. Bitterness and composition of lettuce varieties grown in the southeastern United States. HortTechnology 12:721-726.

Slattery, M.L., J. Benson, K. Curtin, K.N. Ma, D. Schaeffer, and J.D. Potter. 2000. Carotenoids and colon cancer. Amer. J. Clinical Nutr. 71:575-582.

Steel, R.G.D. and J.H. Torrie. 1980. Principles and procedures of statistics. McGraw-Hill, New York.

Terry, N. and J. Abadia. 1986. Function of iron in chloroplasts. J. Plant Nutr. 9(3-7):609-646.

USDA. 2004. U.S. Department of Agriculture, Agricultural Research Service, National Nutrient Database for Standard Reference, Release 17. 27 Mar. 2005. <http://www.nal.usda.gov/fnic/foodcomp/Data/ SR17/sr17.html> 